DOI: $10.15276 /$ ETR.03.2020.5

DOI: 10.5281 /zenodo.4458634

UDC: $338.24 .021 .8: 629.73(477)(043.3 / .5)$

JEL: L22, L62

\title{
STATE OF THE AIR TRANSPORT COMPLEX IN THE SOUTHERN REGION OF UKRAINE IN MODERN CONDITIONS
}

\section{СТАН АВІАТРАНСПОРТНОГО КОМПЛЕКСУ ПІВДЕННОГО РЕГІОНУ УКРАЇНИ У СУЧАСНИХ УМОВАХ}

\author{
Ivan I. Sokoly, DEcon, Professor \\ Odessa National Polytechnic University, Odessa, Ukraine \\ ORCID: 0000-0002-5068-5330 \\ Email: siihcscell@gmail.com \\ Yulia V. Marchuk \\ Odessa National Polytechnic University, Odessa, Ukraine \\ Anissa Busmina \\ Odessa National Polytechnic University, Odessa, Ukraine \\ Odessa National Polytechnic University, Odessa, Ukraine
}

Received 08.06.2020

Соколи I.I., Марчук Ю.В., Бусміна А., Джарджур Р. Стан авіатранспортного комплексу південного регіону України у сучасних умовах. Оглядова стаття.

В статті розглянуто поточний стан аеропортівського вузла південного регіона України у складі аеропортів Одеса, Херсон, Миколаїв, Ізмаїл, Лиманське, та місцевих аеродромів. Робиться висновок, що авіатранспортна система південного регіону знаходиться у незадовільному стані. Головними причинами незадовільного стану аеропортів $є$ повне абстрагування держави від забезпечення їх підтримки та розвитку, незбалансованої програми їх приватизації, та їх неефективний менеджмент за принципом «життя сьогоднішнім днем».

Ключові слова: аеропорт, авіаційний менеджмент, авіатранспортний комплекс, розвиток аеропортів, державна програма розвитку авіації

Sokoly I.I., Marchuk Yu.V., Busmina A., Jarjur R. State of the air transport complex of the southern region of Ukraine in modern conditions. Review article.

In the article it was analysed the current state of the airport hub of the southern region of Ukraine as system of the airports of Odessa, Kherson, Nikolaev, Izmail, Limanskoe, and local airfields. It is concluded that the air transport system of the southern region is in unsatisfactory condition. The main reasons for the unsatisfactory state of airports are the complete abstraction of the state from ensuring their support and development, an unbalanced program for their privatization, and their inefficient management on the principle of "living for today".

Keywords: Airport, Aviation Management, Air Transport complex, Airport Development, State Aviation Development Program
$\mathrm{T}$ he research of the processes of evolution of airport farms in the regions of Ukraine is an important scientific and practical issue in modern conditions. Conclusions about the nature and conditions, advantages and disadvantages, nature and features of regional development of organizational structures of the airport economy of Ukraine form the scientific and practical basis for the development of new effective forms of this category of airlines.

\section{Analysis of recent research and publications}

Some aspects of the processes of evolution of organizational structures in civil aviation of Ukraine were studied by working groups of the Department of air transport of Ukraine [2-4] and researchers of KNAU [5-10], but comprehensive and comprehensive studies of the processes of evolution of airport facilities in the regions of Ukraine over the past 10 years have not been carried out.

\section{Unsolved aspects of the problem}

To develop effective programs for long-term and high-quality development of the regional sector of the civil aviation industry of Ukraine, scientific understanding and systematization of the processes that resulted in the unsatisfactory state of the regional sector of the industry in which it is currently located [9] is required as a scientific and practical basis for determining the directions and methodology for the formation of new effective and promising organizational structures of airport facilities in Ukraine, able to survive in a highly competitive environment and limited opportunities to attract resources. 
The purpose of this work is to provide a scientific description, reveal the essence, trends and features of the evolution of organizational forms of airports in the southern region of Ukraine in 2001-2019, identify their positive and negative aspects, and systematize the results obtained.

\section{The main part}

Odessa airport. At first glance, the successful position of the leading airport "Odessa", which has generally quite high indicators of passenger and cargo traffic, is fraught with a number of closely related economic problems. First of all, it should be noted that despite the seemingly promising trend of increasing the number of flights served every year, this trend is negative for the development of the aviation industry in the region. A significant share and annual increase in new flights to the airport "Odessa" are flights of foreign and powerful capital airlines, while the number of flights of local Odessa airlines is rapidly decreasing from year to year. Local airlines, which are hopelessly inferior to their foreign and Metropolitan competitors in terms of fleet and financial potential, do not withstand competitive pressure, which results in their reducing their production infrastructure to critical levels on the verge of bankruptcy. For example, the state airline "Odessa airlines" during the period of active expansion of the capital and foreign airlines lost almost all of its fleet and was forced to give all its flights to competitors, and is currently in a state of de facto bankruptcy, although it retains the operator's certificate only due to a special order of the state aviation authorities. During the same period, Tavria airlines reduced its fleet from three to one aircraft, and was forced to transfer commercial rights to very promising flights Odessa-Dubai, Odessa-Warsaw and most of the frequencies for the flight Odessa-Istanbul to its foreign and Metropolitan competitors. The third base Odessa airline, Southern airlines, has been displaced by competitors from all scheduled international flights, and the capital's AeroSvit airline is also displacing Southern airlines from the domestic flight Odessa-Kiev. The visible short-term effect of increasing revenues to the local budget from airport fees for take-off and landing and passenger service, as well as the excess profits of private oil traders from selling jet fuel at inadequately inflated prices, are a payment for refusing the possibility of long-term high-quality development of regional civil aviation. As a result, such a state policy of passivity and complete refusal to stimulate and promote the development of regional passenger aviation in the context of the southern region led to the degradation of the once very powerful aviation and technical complex of the Odessa air hub and the air enterprises of Kherson and Nikolaev to several financially very weak and technically weakly competitive airlines that perform one or two regular flights and occasional Charter flights. Odessa airport is the only airport in the southern region of Ukraine that carries out successful and stable production activities with fairly high profitability indicators.
The next two major airports in the region, Kherson and Mykolaiv, are currently experiencing a deep crisis and are unprofitable and unprofitable. The range of flights operated from the international airport "Nikolaev" is reduced to one or two Charter flights no more often than once every two weeks and the regular flight "Nikolaev-Kiev"(Boryspil) introduced in 2016, which is potentially and actually unprofitable.Also from the airport "Nikolaev" flights of the Ka-26 and An-2 aircraft on the use of aviation in the national economy are performed. The financial condition of the airport is characterized as chronically deficient and illiquid, resulting in a complete lack of renewal of fixed assets, a chronic delay in wages for employees and maintenance of airport equipment at the lower limit of acceptable. Airport "Nikolaev" is depressing, hopeless and require rehabilitation. The airport "Kherson" is in even worse condition than the airport "Nikolaev". There are practically no passenger flights from Kherson airport, and the airport's activities are limited to servicing seasonal PANH flights operated by the local airline Kherson-Avia. The financial condition of the airport "Kherson" is characterized as a latent actual bankruptcy, in 2003-2005. Kherson airport could not pass the certification procedure in Ukraviatrans Due to its completely unsatisfactory financial condition and the inability to purchase equipment necessary to maintain a minimum level of flight safety, and was formally closed.The functioning of the airport "Kherson" as well as the airport "Nikolaev" is provided exclusively by subsidies from regional budgets, which is the subject of constant acute dissatisfaction with regional councils, which causes irregular and insufficient funding.

Izmail airport is currently in a rather difficult situation, despite the fact that in recent years its management has managed to ensure a certain number of flights and revenue. At the beginning of the two thousandth years, the airport was going through a crisis period. In 2012, serial Charter flights to Istanbul were launched from Izmail airport with a frequency of at least once a week.There are also seasonal scheduled flights to Kiev from the airport. Currently, Izmail airport operates relatively stable, but with minimal levels of profitability, a significant part of the airport's revenue is covered by subsidies from the city and regional budgets, despite the fact that in General, the Izmail international airport enterprise is unprofitable. The level of airport equipment is generally considered satisfactory, but is actually at the lower limit of the norm.

Airport "Limanskoye" at the present time is practically not functioning. Conceived at the time as an alternative for the Odessa airport to accept multitonnage final and transit cargo flights and later received an international certificate, Limanskoe airport was not able to reach either the estimated airporta or the minimum volumes of flight service. The objective reasons for the failure of this project, despite the significant amount of investment, was a sharp decline in air cargo transportation to the region due to a significant rise in the price of jet fuel and a drop in demand for imported consumer goods. 
Subjective reasons were the inability of the airport management to attract cargo flows and provide a flexible commercial policy, as well as a flexible transport link "Limanskoe - Odessa". As a result, the remaining cargo flights are operated to the airport "Odessa", and the main activity of the airport "Limanskoe" is reduced to providing Parking places for aircraft that have run out of resources, and providing the status of a formal base airport for PANH airlines that actually operate in other regions of Ukraine. Also, from the Limanskoe airport, lightengine and sports aviation flights and parachutists are carried out. Limanskoe airport, being a commercial enterprise in the form of an LLC, is unprofitable and unprofitable and exists at the expense of the founders and investors who still retain a real interest in the airport and have plans for its revival in the future.

The system of local airports and runways for passenger transportation in small regional centers and large villages is currently almost non-existent. Local airports, even in such major regional centers as Belgorod-Dniester, Kilia, Balta and Kotovsk, are closed for passenger flights even formally, although they still retain the remnants of the former production infrastructure, which are under conservation, which can be brought into working condition if sufficient funding is provided

As a result, based on the above analysis, we come to the conclusion that the General condition of the airport complex in the southern region of Ukraine in modern conditions can be defined as unsatisfactory. First of all, it should be noted that the concept of "Odessa air hub" or "southern region air hub" as a balanced, systematized and synchronously functioning complex does not exist. At present, the air transport system of the southern region, which we understand as the "Odessa air hub", is an almost unordered and very poorly connected set of airport farms and air carriers based in them. Based on world experience, which has been in sharp contrast in recent years, we can conclude that such a state of Affairs in a European civilized country with a market economy is absolutely unacceptable. In almost all developed countries and developing countries aspiring to them, integrated, closely interconnected and synchronously functioning air hubs are being formed within the regions, ensuring the most optimal commercial load of air carriers and airports, maximum travel opportunities, convenience and comfort for passengers, and effective counteraction to external competitors through the consolidation and synergy of their own resources and capabilities. Airports and airlines operating independently of each other split and disorganize passenger traffic, thus exhausting themselves with internal competition, which results in a distributed passenger flow that does not give a costeffective load to each individual airport or airline, resulting in losses and a crisis state that is currently taking place in the airports of the southern region of Ukraine. In the conditions of a tough external competitive threat, according to the generally accepted modern scientific positions [], when competitors are obviously stronger, the most effective means of countering competition is the harmonious consolidation of internal market entities, otherwise the failure to take such measures leads to a fairly rapid reduction of internal market entities by external competitors, a process that we are currently observing from the perspective of local Odessa airlines. The region's leadership is aware of the real threat of external competitors, which threatens to completely bankrupt local regional airlines, but due to the lack of clearly designed, balanced and feasible programs, this serious aspect of the region's economy remains without real assistance, protection and stimulation of the state. According to experts ' forecasts [], if this situation persists, passenger aviation in the southern region of Ukraine will be completely destroyed by competitors in 2-3 years.

A somewhat modified situation is seen in the area of airports in the region. The state's inattention to the problems of loading regional airports leads in itioga to the loss of a significant part of revenue from servicing flights through these airports and the degradation of the air transport sector in the region, leading to the loss of jobs and the loss of capital-intensive and hightech elements of the regional transport economy that bring high profits and are the basis for the qualitative development of the region. Simple and extremely low loading of all airports in the region except Odessa International airport has led to the outflow and loss of valuable qualified airport personnel, obsolescence, dilapidation and destruction of airport structures and equipment, which threatens flight safety and people's lives on the one hand, but on the other hand, the maintenance of such unprofitable facilities turns into a significant expense item for local (regional and municipal) budgets, the justification of which causes conflicts and disputes, in this regard, their funding is not sufficiently small and with unacceptable regularity. As a result, residents of districts and regions whose solvency is currently reaching a level acceptable for aviation are completely deprived of the opportunity to use local air transport services, and are forced to spend considerable time on the way by car to the Odessa hub airport.

\section{Conclusions}

The main reason for the crisis in the civil aviation sector in the region was the passive role of the state in stimulating the development of the industry and its non-interference in market processes in terms of protecting domestic airlines from foreign competitors. The passive role of the state in stimulating the development of the industry was based on the almost complete absence of plans and programs to strengthen the position and development of regional civil aviation, and consisted in:

- complete abstraction of the state from the issues of ensuring the system of local air lines and its complete refusal to solve the problems of local airports;

- complete abstraction of the state from the issue of ensuring normal production load of the bulk of regional airports, although these airports were state-owned entities; 
- the complete absence of any measures aimed at stimulating the development of regional passenger and cargo aviation (the regime of tax incentives, compensation for the costs of aviation activities and the establishment of fixed preferential tariffs for aviation fuel, direct budget investment, concessional lending and innovative programs);

- active implementation of the policy of fragmentation, structural degradation and decomposition of complex, viable and stable complex structures of Aeroflot and the formation of a disordered set of primitive and weak aviation entities that do not form almost any qualitative links between them.

The non-interference of the state in market processes in terms of protecting the interests of regional airlines from foreign competitors was based on the absence of any programs and installations both at the national and regional levels to protect domestic regional airlines from powerful foreign competitors, which are in obviously worse conditions in terms of financial opportunities and a weakly competitive outdated fleet, and:
- Application of almost identical fare systems for domestic and foreign airlines at airports in the regions of Ukraine;

- Abstraction of the state from assistance in ensuring the technical re-equipment of the fleet with new competitive equipment;

- Complete absence of state programs for the introduction of new management technologies in the field of creating effective coplex avivtransport structures, in which the state also acts as a project participant.

The next important reason for the decline in civil aviation in the region was the primitive and shortsighted management of regional airlines and airports, which was expressed in:

- an extensive approach to fleet operation, when airlines "lived for today", developing the remaining resources of outdated Soviet aircraft, completely not caring about forimirovanii funds for fleet renewal;

- a passive approach to the use of methods of collective structural organization of subjects through consolidation and integration to resist external tough competition.

\footnotetext{
Abstract

The main reason for the crisis in the civil aviation sector in the region was the passive role of the state in stimulating the development of the industry and its non-interference in market processes in terms of protecting domestic airlines from foreign competitors:

- complete abstraction of the state from the issues of ensuring the system of local air lines and its complete refusal to solve the problems of local airports;

- complete abstraction of the state from the issue of ensuring normal production load of the bulk of regional airports, although these airports were state-owned entities;

— the complete absence of any measures aimed at stimulating the development of regional passenger and cargo aviation;

- active implementation of the policy of fragmentation, structural degradation and decomposition of complex, viable and stable complex structures of Aeroflot and the formation of a disordered set of primitive and weak aviation companies.

The non-interference of the state in market processes in terms of protecting the interests of regional airlines from foreign competitors:

- Application of almost identical fare systems for domestic and foreign airlines at airports;

- Abstraction of the state from assistance in ensuring the technical re-equipment of the fleet with new competitive equipment;

- Absence of state programs for the introduction of new management technologies.

The next important reason for the decline in civil aviation in the region was the primitive and short-sighted management of regional airlines and airports, which was expressed in:

— an extensive approach to fleet operation, when airlines "lived for today", developing the remaining resources of outdated Soviet aircraft, completely not caring about forimirovanii funds for fleet renewal;

- a passive approach to the use of methods of collective structural organization of subjects through consolidation and integration to resist external tough competition.
}

\section{Список літератури:}

1. Журнал «Forbes» «200 найбільших компаній світу», листопад 2019 року [Електронний ресурс]. Режим доступу: http://forbes.ua.

2. Розвиток підприємства: концепція і технологія дослідження [текст] монографія / I. M. Капаруліна. - Київ: Центр учбової літератури, 2018. - 432 с.

3. Журнал «Flight International» Раздел «Анализ», листопад 2018 року [Електронний ресурс]. Режим доступу https://www.flightglobal.com/news/articles/analysis-a-year-in-aerospace-the-top-11moments-of-431808/ 
4. Офіційний сайт концерну «Антонов» [Електронний ресурс]. - Режим доступу: http://www.antonov.com.

5. Офіційний сайт АТ «Мотор Січ» [Електронний ресурс]. - Режим доступу: http://www.motorsich.com/.

6. Офіційний сайт ХГАПП [Електронний ресурс]. - Режим доступу: www.ksamc.com/.

\section{References:}

1. Forbes Magazine "200 largest companies in the world". Retrieved from http://forbes.ua [in Ukrainian].

2. Kaparulina I.M. (2018). Enterprise development: concept and technology of research [in Ukrainian].

3. Flight International Magazine, Analysis Section. Retrieved from https://www.flightglobal.com/news /articles/analysis-a-year-in-aerospace-the-top-11-moments-of-431808/ [in Russian].

4. Official Site of "Antonov" Concern. www.antonov.com. Retrieved from http://www.antonov.com [in Ukrainian].

5. Official Site of "Motor Sich" JSC. www.motorsich.com. Retrieved from http://www.motorsich.com/ [in Ukrainian].

6. Official Site of KSAMC. www.ksamc.com. Retrieved from www.ksamc.com/ [in Ukrainian].

\section{Посилання на статтю:}

Sokoly I.I.. State of the air transport complex of the southern region of Ukraine in modern conditions / I .I. Sokoly, Yu. V. Marchuk, A. Вusmina, R. Jarjur // Економіка: реалії часу. Науковий журнал. - 2020. - № 3 (49). - C. $42-$ 46. - Режим доступу до журн.: https://economics.opu.ua/files/archive/2020/No3/42.pdf. DOI: 10.15276/ETR.03.2020.5. DOI: 10.5281/zenodo.4458634.

\section{Reference a Journal Article:}

Sokoly I.I.. State of the air transport complex of the southern region of Ukraine in modern conditions / I.I. Sokoly, Yu. V. Marchuk, A. Busmina, R. Jarjur // Economics: time realities. Scientific journal.- 2020. - № 3 (49).- P. 4246. - Retrieved from https://economics.opu.ua/files/archive/2020/No3/42.pdf.

DOI: 10.15276/ETR.03.2020.5. DOI: 10.5281/zenodo.4458634. 